\title{
Imaging Techniques for Both Diagnosing Individuals with Dermatologic Conditions and Doing Clinical Research: A Selection of Our Contribution to this Field
}

\section{Monika Bowszyc-Dmochowska ${ }^{1} \mid$ Marian Dmochowski ${ }^{2 *}$}

*Correspondence: Prof. Marian Dmochowski

Address: ${ }^{1}$ Cutaneous Histopathology and Immunopathology Section; ${ }^{2}$ Autoimmune Blistering Dermatoses Section, Department of Dermatology, Poznan University of Medical Sciences, Poland

e-mail $₫$ mkdmoch@wp.pl

Received: 19 November 2019; Accepted: 20 January 2020

Copyright: (C) 2020 Dmochowska MB, et al. This is an open-access article distributed under the terms of the Creative Commons Attribution License, which permits unrestricted use, distribution, and reproduction in any medium, provided the original author and source are credited

\section{ABSTRACT}

Imaging techniques are used for diagnosing dermatologic conditions from the conception of dermatology as a separate medical specialty. Nowadays, they can be combined with biochemical-molecular techniques to serve as even better diagnostic tool. Direct immunofluorescence (DIF) is a golden standard for routinely diagnosing autoimmune blistering diseases. DIF images can be visualized with short arc mercury lamp-operated microscopy, blue light-emitting diode technology-operated microscopy and laser scanning confocal microscopy. Advanced microscopy methods, such as ex vivo confocal laser scanning microscopy, atomic-force microscopy/scanning-force microscopy, multiphoton microscopy, super/high resolution techniques known under acronyms STED, GSDIM/dSTORM (Ground State Depletion followed by Individual Molecule return/direct Stochastic Optical Reconstruction Microscopy) can conceptually be applied to every-day laboratory practice. Three-tier approach to diagnosing individuals suffering from dermatologic ailments, namely clinical evaluation, imaging techniques, biochemical-molecular techniques is still indispensable in managing dermatologic patients.

Keywords: Dermatologic conditions, Clinical research, Imaging techniques

\section{A selection of our contribution to the field of imaging techniques in autoimmune bullous diseases in the $21^{\text {st }}$ century}

Our clinical-laboratory-research activity on autoimmune bullous diseases (Dmochowski, 2003; Schmidt et al., 2015) has yielded several series of publications. The first is a continuation of research on the pathogenesis of bullous pemphigoid (BP). We have published articles on the role of autoantibodies against principal BP antigens and their most immunogenic fragments, on relationships between their concentrations and exacerbation of the inflammatory reaction with the participation of stimulated inflammatory cells; neutrophils and eosinophils, and on their effect on remodelling of the dermoepidermal junction: Eosinophil major basic protein (MBP), IL-5, neutrophil elastase and IL-8 in 
blistering skin in relation to IgG serum antibodies to NC16a in human bullous pemphigoid (Wolnik et al., 2005) and Autoimmunity-driven enzymatic remodeling of the dermal-epidermal junction in bullous pemphigoid and dermatitis herpetiformis (Gornowicz et al., 2012a). This was also associated with the introduction of the ELISA method (enzyme-linked immunosorbent assay) in our centre in BP work-up. ELISA has currently replaced the previously used indirect immunofluorescence. We have confirmed that sera of patients much more often contain anti-BP180 antibodies than anti-BP230 antibodies: The BP180 IgG ELISA is superior to the BP230 IgG ELISA for diagnosis IgG-mediated subepidermal autoimmune blistering dermatoses (Gornowicz et al., 2012b), and that the antibody concentration in blister fluid is similar to its serum level: Levels of IgG antibodies to BP180 are not significantly different in blister fluids and sera in patients with bullous pemphigoid - a pilot study (Bowszyc and Dmochowski, 2008).

The next series investigated the pathogenesis and diagnosis of dermatitis herpetiformis (DH). In total, it contains 23 papers with my authorship and includes a study on the role of autoimmunity to epidermal and tissue transglutaminases, which was a subject of a doctoral dissertation of Dr Grazyna Wolnik-Trzeciak, written under our supervision: Autoimmunity to epidermal and tissue transglutaminase with reference to selected factors of skin pathogenesis of dermatitis herpetiformis (Wolnik, 2005), and other publications, such as: Association between levels of IgA antibodies to tissue transglutaminase and gliadin-related nonapeptides in dermatitis herpetiformis (Gornowicz et al., 2012c), IgA autoantibodies to gliadin nonapeptides, tissue transglutaminase and epidermal transglutaminase are associated, but unrelated to neutrophil elastase expression in lesional skin in human dermatitis herpetiformis (Gornowicz et al., 2012d), Autoimmunity-driven enzymatic remodeling of the dermal-epidermal junction in bullous pemphigoid and dermatitis herpetiformis (Gornowicz et al., 2012a), Cutaneous expressions of interleukin-6 and neutrophil elastase as well as levels of serum IgA antibodies to gliadin nonapeptides, tissue transglutaminase and epidermal transglutaminase: implications for both autoimmunity and autoinflammation involvement in dermatitis herpetiformis (Gornowicz et al., 2014), Immunoexpression of IgA receptors (CD89, CD71) in dermatitis herpetiformis (Gornowicz et al., 2017). Studies on the role of autoimmunity to transglutaminases in the pathogenesis of DH were innovative at that time. Our centre was one of the first to have extended the routine $\mathrm{DH}$ work-up with a molecular-based assay of IgA antibodies against epidermal transglutaminase and then against tissue transglutaminase as an equivalent method, which is more sensitive and specific for detection of anti-endomysial antibodies than previously used immunofluorescence; this was corroborated in studies. We also tested the presence of IgA antibodies against gliadin nonapeptides and investigated their relevance in DH. We demonstrated that they are not more specific than anti-tTG antibodies used in the work-up, and were therefore not introduced to routine diagnosis. Further studies focussed on the role of auto inflammation in the pathogenesis of $\mathrm{DH}$, and particularly on the role of 
eosinophils and neutrophils and their enzymes in dermo-epidermal junction remodeling and damage, the effect of which is blister formation. Another focus was their receptor-mediated interactions with tissue-bound autoantibodies.

The next series also concerned the introduction of novel methods and perfection of laboratory diagnostic techniques in other autoimmune bullous dermatoses. One of them was the application of direct immunofluorescence study on a plucked scalp hair (hDIF) in bullous dermatosis. The incentive for the study was the detection of antibody deposition in the outer sheath of hair follicles collected using a traditional biopsy technique, and detection of the principal autoantigens of bullous dermatosis in the outer sheath of hair follicles in an immunohistochemical study: Clinical, microscopic and molecular aspects of the hair follicle in autoimmune blistering dermatoses. (Wolnik et al., 2006). The project entitled: "The deposits of immunoglobulins in the hair follicle and antibodies against desmogleins in the patients with pemphigus and their relatives." was conducted under our supervision in 2005- 2007 and supported financially by Poznan University of Medical Sciences as part of our own individual research. The method of material collection, freezing, section preparation and immunofluorescent staining were developed. The method occurred to be as reliable as conventional DIF, particularly with respect to pemphigus vulgaris and slightly less with respect to pemphigus foliaceus: Deposits of IgG, IgG1 and IgG4 in hair follicles in relation to antibodies to desmoglein 1 and 3 in pemphigus (Danczak et al., 2004) or autoimmune diseases involving dermo-epidermal junction proteins. This method was also used for the diagnosis of IgA-mediated blistering disorders: Pemphigus pattern of IgA deposits in hair follicles in a patient with IgA pemphigus of intraepidermal neutrophilic type (Bowszyc et al., 2007). Autoantibody deposition was identified in patient hair plucked from both affected and unchanged scalp. A case of mucosal-dominant variety of pemphigus vulgaris with laryngeal lesions and pemphigus deposits in hair plucked from clinically unchanged skin (Danczak et al., 2010). Non-invasiveness was the advantage. By contrast with the traditional invasive method, the discussed technique could be repeated and used for disease monitoring. Control examinations were conducted in healthy relatives who showed no signs of autoantibody deposition, which confirmed the pathogenetic importance of these deposits: Lack of pemphigus hair follicle deposits of immunoreactants in pemphigus-free biological kin of patients with nonendemic pemphigus. Concise communication (Dmochowski and Bowszyc, 2007). In total, 9 articles were devoted to this subject. It was also the main topic of the doctoral dissertation of Aleksandra Danczak-Pazdrowska, entitled: IgG, IgG1 i IgG4 antibodies against desmoglein 1 in pemphigus, supervised by Marian Dmochowski (Danczak, 2005).

Another issue linked with both perfection of diagnostic techniques and academic activity was the continuation of studies initiated prior to Assistant Professorship of Monika Bowszyc-Dmochowska, 
namely those on subclasses of autoantibodies in the pathogenesis of autoimmune bullous diseases. The predominant subclass in all IgG-mediated bullous dermatoses, except for gestational pemphigoid, is IgG4 both in tissue deposits and among circulating antibodies. It is typical of the active phase of the disease, which confirms the role of TH-2 response at this stage. The introduction of IgG1 and IgG4 to routine DIF has increased the sensitivity and specificity of this test significantly. By extending the antibody panel by these two subclasses, we also modified ssDIF and hDIF methods: Pemphigus vulgaris in two brothers. Pemphigus IgG4 deposits in hair follicles (Danczak et al., 2003). The application of monoclonal anti-fluorescein-conjugated IgG4 antibody markedly improved the specificity and sensitivity of circulating antibody detection in indirect immunofluorescence (IIF) on the commercial substrate of the monkey oesophagus and on later introduced multi-substrate mosaics for detection of circulating antibodies in the diagnostic workup of autoimmune bullous dermatoses: Immunoglobulin G4 is prevailing over immunoglobulin G1 in autoimmunity of pemphigus and bullous pemphigoid: analysis of tissue-bound antibodies in active diseases (Gornowicz et al., 2013). We aimed at introducing and comparative analysis of the usefulness of multiparametric tests whose goal is to test as many antibodies in a single sample as possible. Another test evaluated by us in a comparative analysis and lately introduced to the diagnostic work-up is multiparametric ELISA used for the detection of antibodies against basic autoantigens of bullous diseases in a single test: Dsg1 and 3, BP180, BP230, envoplakin and type VII collagen. Moreover, a description of the types of tissue deposits containing antibodies in dermatitis herpetiformis was an original contribution to the laboratory work-up of bullous diseases: finely granular IgA deposits in dermal papillae, finely granular IgA deposits along the dermo-epidermal junction and fibrillary IgA deposits in dermal papillae. This should facilitate the diagnosis of this disease based on DIF - the primary diagnostic method in DH: On patterns of IgA deposits in the skin of patients with dermatitis herpetiformis (Dmochowski et al., 2003a) and in pemphigus, where, next to linear, continuous and fish-net-like deposits in epidermal intercellular spaces, as described in textbooks, there are also non-continuous deposits that resemble dew drops on a spider web, especially in its lower parts; they are as common and typical as the previously mentioned deposits, but they remained unnoticed. The awareness of the pathogenetic relevance of these deposits in pemphigus, especially with the absence of a typical deposition pattern, helps avoid false negative results: Dew drops on spider web appearance: a newly named pattern of IgG4 deposition in pemphigus with direct immunofluorescence (Dmochowski et al., 2017). DIF images can be visualized with short arc mercury lamp-operated microscopy, blue light-emitting diode technology-operated microscopy and laser scanning confocal microscopy with comparable efficiency (Gornowicz et al., 2019).

The second field of study associated with blistering disorders is the search for triggering factors of autoimmunity to autoantigens of bullous dermatoses and for relationships of these conditions with 
other diseases. Typical triggering factors are: cancers, drugs and physical factors, such as trauma or X radiation. Malignancy may precede the onset, develop during the active phase of the disease or in the remission period, and may coexist with any of the autoimmune bullous diseases, thus significantly complicating the course and treatment of both conditions. Our data suggest that the risk of cancer is the lowest in patients with DH and the highest in those with BP (excluding paraneoplastic pemphigus - an extremely rare form of pemphigus). This problem was addressed in the chapter entitled: Malignancy in relation to autoimmune blistering dermatoses: molecular and clinical aspects in: Highlights in skin cancer. Ed. by: Pierre Vereecken (Pietkiewicz et al., 2013), and in numerous case reports of which we were co-authors, such as: Mucocutaneous pemphigus vulgaris in a patient with oral squamous cell carcinoma treated with radiotherapy (Chruslinski et al., 2009), A case of trauma-induced and paraneoplastic bullous pemphigoid (Dmochowski et al., 2008) or Linear IgA bullous dermatosis in a patient with hairy cell leucaemia in remission - a case study and review of the literature (Dmochowski et al., 2003b).

Other triggering factors of autoimmune dermatoses are drugs and foods. In pemphigus, these are mainly products with thiol groups and other drugs used mainly in the treatment of hypertension and circulatory insufficiency, such as ACE inhibitors, ARBs, calcium channel blockers, sulphonamides and thiazides, as well as other environmental factors. We have published a number of articles discussing these issues: A retrospective study of antihypertensives in pemphigus: a still unchartered odyssey particularly between thiols, amides and phenols (Pietkiewicz et al., 2015), Mucosal-dominant pemphigus vulgaris in a captopril-taking woman with angioedema (Gornowicz et al., 2015), A combination of exogenous and endogenous factors as a possible trigger of pemphigus vulgaris - case report and review of literature (Danczak et al., 2005), Reviewing putative industrial triggering in pemphigus: cluster of pemphigus in the area near the wastewater treatment plant (Pietkiewicz et al., 2017). Interestingly, despite a known role of certain drugs as pemphigus-triggering factors and as factors that sustain the active disease process, many patients with active disease continue to take these medications.

Subsequent studies were devoted to drugs and foods that elicit dermatitis herpetiformis, except for those with gluten or iodine: Transient manifestation of dermatitis herpetiformis in a female with familial predisposition induced by propafenone (Dus et al., 2009), Interferon- $\alpha$ and dermatitis herpetiformis (Dmochowski et al., 2007).

Another area of our activity is investigation into the pathogenetic relationships of bullous pemphigoid and neurodegenerative disorders, which occur more often in this group of patients. A comparative analysis of anti-neuronal antibody profiles (immunoblotting) in patients with BP and with 
or without a neurodegenerative disorder was performed: Neurodegenerative disorders, bullous pemphigoid and psoriasis: a comparative study in ethnic Poles indicates that Parkinson's disease is more relevant to bullous pemphigoid (Bartkiewicz et al., 2017), These issues are addressed in a doctoral dissertation of Pawel Bartkiewicz, entitled: "Issues of triggering factors and comorbidities in autoimmune blistering dermatoses" and supervised by Marian Dmochowski, Monika BowszycDmochowska and Justyna Gornowicz-Porowska (Bartkiewicz, 2019).

The third area of our academic activity comprises skin cancers, carcinogenesis as well as diagnosis and treatment. This subject matter was addressed in innovative studies on the role of desmosomal cadherins in basal cell carcinoma conducted in 2008-2010 as part of the Poznan University of Medical Sciences grant: "Desmogleins in malignancy and autoimmunisation" No 501-01-222064705968. The investigation involved the analysis of desmoglein (Dsg) 2, 3 and 4 expression using immunohistochemistry and in situ hybridisation in basal cell carcinomas with a division into clinical and histological types and a comparison with their expression in the healthy epidermis. These studies demonstrated that basal cell carcinoma is accompanied by a higher Dsg 2 and lower Dsg 3 expression compared with the healthy epidermis: Quantitative digital morphometry reveals low expression of desmoglein 3 protein in basal cell carcinomas: relevance to pemphigus vulgaris pathogenesis? (Gornowicz et al., 2009) (this paper was deemed the best article in the field of dermatological oncology published in Dermatologia Kliniczna in 2009 and was awarded the Feliks Wasik Award), Loss of correlation between intensities of desmoglein 2 and desmoglein 3 expression in basal cell carcinomas (Gornowicz et al., 2011), Discordant expression of desmoglein 2 and 3 at the mRNA and protein levels in nodular and superficial basal cell carcinoma revealed by immunohistochemistry and fluorescent in situ hybridization (Pietkiewicz et al., 2014a), Desmosomal cadherins in basal cell carcinomas. In: Skin cancer overview. Ed. by: Yaguang Xi (Gornowicz, 2011). This subject is also discussed in the doctoral dissertation of Pawel Pietiewicz, entitled: "Desmoglein expression in basal cell carcinomas in the relation to clinico-pathological fetures of the neoplasm" supervised by us (Pietkiewicz et al., 2014b).

Imaging techniques outside autoimmune bullous diseases in the $21^{\text {st }}$ century

Furthermore, Monika Bowszyc-Dmochowska has also been actively engaged in studies on the role of cycooxygenase- 2 in the pathogenesis of actinic keratosis: Cyclooxygenase- 2 expression in actinic keratosis (Adamska et al., 2018). She has been the co-author of the review on skin cancers: Basal cell carcinoma - diagnosis (Mackiewicz et al., 2013) - the most frequently cited work of all her publications). This was an innovative work due to the comprehensive approach to the diagnostic process, including clinical, ultrasonographic and histopathological assessment of this cancer, which is characterised by various clinical and histological forms. The previous paper concerned epidemiology of 
basal cell carcinoma: Analysis of the appearance of different histological types of basal cell carcinoma, localization of the lesions, the age and sex of patients (Deja et al., 2004). The problem of cancers and pre-cancerous conditions induced by ultraviolet radiation was addressed in a part of the following review paper: Effect of ultraviolet radiation on skin : acute and chronic sun-damage (Bowszyc, 2010), while cryosurgery in pre-cancerous conditions and cancers was discussed in: Cryosurgery in dermatology and esthetic medicine (Bowszyc, 2015) and in a textbook of which she was a co-author: Cryosurgery in skin diseases (Kazmierowski and Bowszyc, 2017). In addition, she has been a co-author of 8 published case reports and various conference communications about malignant and benign skin cancers.

Other issues which she deals with both practically and academically are photobiology and phototherapy. In 2006, this was a subject of the doctoral dissertation of Dr Magdalena Luczkowska, entitled: "Concentration of TNF- $\alpha$ in serum of psoriasis patients treated with phototherapy and retinoids" (Luczkowska, 2006). The study demonstrated that effective therapy induces minor changes in the serum TNF $\alpha$ level, but significantly alters serum concentrations of TNF $\alpha$ receptor. Other articles on this problem include: Phototherapy in dermatology (Bowszyc, 2006), Effect of ultraviolet radiation on skin: acute and chronic sun-damage (Bowszyc, 2010), A case of a Comel-Netherton syndrome patient treated with UVA1 phototherapy (Osmola et al., 2011), Use of UVA1 in the treatment of mycosis fungoides - case report (Olek et al., 2011).

She is also engaged in evaluating imaging, non-invasive method in dermatology aiming at establishing their clinical usefulness. Her responsibilities include performing histopathological examinations to confirm ultrasound findings. This has yielded several publications, including: Highfrequency ultrasonography - new non-invasive method in assessment of skin lymphomas (Polanska et al., 2018), High-frequency ultrasonography (20 MHz) in circumscribed palmar hypokeratosis - new observations (Polanska et al., 2016), and High-frequency ultrasonography a new quantitative method in evaluation of skin lymphomas-First comparative study in relation to histopathology (Polanska et al., 2019).

\section{References}

Adamska K, Pawlaczyk M, Bowszyc-Dmochowska M, Gornowicz-Piotrowska J, Janicka-Jedynska M, Fedorowicz T, Zaba R. Cyclooxygenase-2 expression in actinic keratosis. Adv Dermatol Allergol 2018; 35: 626-630.

Bartkiewicz P, Gornowicz-Porowska J, Pietkiewicz PP, Swirkowicz A, Bowszyc-Dmochowska M, Dmochowski M. Neurodegenerative disorders, bullous pemphigoid and psoriasis: a comparative study in ethnic Poles indicates that Parkinson's disease is more relevant to bullous pemphigoid. Adv Dermatol Allergol 2017; 34: 42-46.

Bartkiewicz P. Zagadnienia czynnikow wyzwalajacych i chorob wspolistniejacychw autoimmunizacyjnych dermatozach 
pecherzowych/Issues of triggering factors and comorbidities in autoimmune blistering dermatoses. Poznan 2019; 1-166.

Bowszyc-Dmochowska M and Dmochowski M. Poziomy przeciwcial IgG przeciwko BP180 w plynach pecherzowych i surowicach nie roznia sie znamiennie u chorych na pemfigoid pecherzowy -badanie wstepne. Dermatologia Kliniczna 2008; 10: 7-8.

Bowszyc-Dmochowska M and Dmochowski M.Pecherzycowe zlogi IgA w mieszku wlosowym u chorej na pecherzyce IgA typu srodnaskorkowego neutrofilowego. Dermatologia Kliniczna 2007; 9: 141-142.

Bowszyc-Dmochowska M. Dzialanie promieniowania ultrafioletowego na skore. Ostre i przewlekle uszkodzenie posloneczne/Effect of ultraviolet radiation on skin : acute and chronic sun-damage. Homines Hominibus 2010; 6: 29-41

Bowszyc-Dmochowska M. Fototerapia w dermatologii/Phototherapy in dermatology. Przew Lek 2006; 89: 85-91.

Bowszyc-Dmochowska M. Krioterapia w dermatologii i medycynie estetycznej. Aesthetica 2015; 5: 40-50.

Chruslinski A, Niskiewicz I, Puchala A, Zajkowska M, Budzinska A, Bowszyc-Dmochowska M, Stryczynska G, Adamiak E, Bajon T, Breborowicz J, Gornowicz J, Dmochowski M. Przypadek sluzowkowo-skornej odmiany pecherzycy zwyklej w przebiegu raka plaskonablonkowego w obrebie jamy ustnej leczonego radioterapia. Dermatologia Kliniczna 2009; 11:37-41.

Danczak-Pazdrowska A, Bowszyc-Dmochowska M, Mariak I, Dmochowski M. Pecherzyca zwykla u dwoch braci. Pecherzycowe zlogi IgG4 w mieszkach wlosowych. Adv Dermatol Allergol 2003; 20: 365-370.

Danczak-Pazdrowska A, Bowszyc-Dmochowska M, Prokop J, Wolnik-Trzeciak G, Dmochowski M. Wspoldzialanie czynnikow zewnatrz- i wewnatrzpochodnych w powstawaniu pecherzycy zwyklej-opis przypadku i przeglad literatury. Adv Dermatol Allergol 2005; 7: 29-34.

Danczak-Pazdrowska A, Bowszyc-Dmochowska M, Wolnik-Trzeciak G, Dmochowski M. Zlogi IgG, IgG1 i IgG4 w mieszkach wlosowych a przeciwciala IgG, IgG1 i IgG4 przeciwko desmogleinom w pecherzycy. Dermatologia Kliniczna 2004; 6: 207-213.

Danczak-Pazdrowska A, Pazdrowski J, Bowszyc-Dmochowska M, Dmochowski M. Zmiany w krtani w pecherzycy zwyklej z dominacja zmian na blonach sluzowych. Otolaryngologia Polska 2010; 61: 509-512.

Danczak-Pazdrowska A. Przeciwciala IgG, IgG1 i IgG4 przeciwko desmogleinie $1 \mathrm{w}$ chorobach kregu pecherzycy. Poznan 2005: 1-107.

Deja M, Teresiak E, Buczynska-Gorna M, Karas A, Jenerowicz D, Bowszyc-Dmochowska M. Analiza czestosci wystepowania poszczegolnych typow histologicznych raka podstawnokomorkowego skory, umiejscowienia zmian oraz wieku i plci pacjentow/Analysis of the appearance of different histological types of basal cell carcinoma, localization of the lesions, the age and sex of patients. Adv Dermatol Allergol 2004; 21: 231-239.

Dmochowski M and Bowszyc-Dmochowska M. Brak pecherzycowych mieszkowych zlogow immunoreaktantow u biologicznych krewnych bez pecherzycy chorych na pecherzyce nieendemiczna. Doniesienie wstepne. Dermatologia Kliniczna 2007; 9: 211-212.

Dmochowski M, Bowszyc-Dmochowska M, Danczak-Pazdrowska A. O typach zlogow IgA w skorze chorych na opryszczkowate zapalenie skory. Adv Dermatol Allergol 2003a; 20: 46-48.

Dmochowski M, Danczak-Pazdrowska A, Bowszyc-Dmochowska M, Raszeja-Kotelba B. Linijna IgA dermatoza pecherzowa u pacjenta z przewlekla bialaczka wlochatokomorkowa w okresie remisji: opis przypadku i przeglad literatury. Adv Dermatol Allergol 2003b; 20: 106-112.

Dmochowski M, Danuta Januszkiewicz-Lewandowska D, Bowszyc-Dmochowska M. Interferon alpha a opryszczkowate zapalenie skory. Dermatologia Kliniczna 2007; 9: 237-238. 
Dmochowski M, Fuksiewicz W, Turczuk-Bierla I, Bowszyc-Dmochowska M. Przypadek pemfigoidu pecherzowego indukowanego urazem i paraneoplastycznego. Dermatologia Kliniczna 2008; 10: 45-46.

Dmochowski M, Gornowicz-Porowska J, Bowszyc-Dmochowska M. Dew drops on spider web appearance: a newly named pattern of IgG4 deposition in pemphigus with direct immunofluorescence. Adv Dermatol Allergol 2017; 34: 295 -298.

Dmochowski M. The classification of blistering autoimmune dermatoses according to M. Dmochowski. Post Derm Alergol 2003; $20: 164$.

Dus M, Danczak-Pazdrowska A, Gornowicz J, Bowszyc-Dmochowska M, Dmochowski M. Przejsciowe ujawnienie sie opryszczkowatego zapalenia skory u kobiety z predyspozycja rodzinna wywolane przyjmowaniem propafenonu. Adv Dermatol Allergol 2009; 26: 239-242.

Gornowicz J, Bowszyc-Dmochowska M, Seraszek A, Kaczmarek E, Dmochowski M. Quantitative digital morphometry reveals low expression of desmoglein 3 protein in basal cell carcinomas: relevance to pemphigus vulgaris pathogenesis?. Drmatologia Kliniczna 2009; 11: 191-194.

Gornowicz-Porowska J, Bowszyc-Dmochowska M, Dmochowski M. Autoimmunity-driven enzymatic remodeling of the dermal-epidermal junction in bullous pemphigoid and dermatitis herpetiformis. Autoimmunity 2012a; 45: 71-80.

Gornowicz-Porowska J, Bowszyc-Dmochowska M, Dmochowski M. Desmosomal cadherins in basal cell carcinomas. In: Skin Cancer Overview. 2011 Ed. Yaguang Xi, ISBN 978-953-307-746-8. Publisher: InTech, Rijeka, Croatia (http://www.intechopen.com/books/show/title/skin-cancer-overview).

Gornowicz-Porowska J, Bowszyc-Dmochowska M, Raptis-Bolwach M, Seraszek-Jaros A, Kaczmarek E, Dmochowski M. Blue light-emitting diode technology-operated microscopy is preferable to both short arc mercury lamp-operated microscopy and laser scanning confocal microscopy for direct immunofluorescence images evaluation in routinely diagnosing subepidermal autoimmune blistering diseases. Microsc Res Tech 2019; 82: 1735-1740.

Gornowicz-Porowska J, Bowszyc-Dmochowska M, Seraszek-Jaros A, Kaczmarek E, Dmochowski M. Association between levels of IgA antibodies to tissue transglutaminase and gliadin-related nonapeptides in dermatitis herpetiformis. Scientific World Journal 2012c; 2012: 363296.

Gornowicz-Porowska J, Bowszyc-Dmochowska M, Seraszek-Jaros A, Kaczmarek E, Pietkiewicz P, Dmochowski M. Cutaneous expressions of interleukin-6 and neutrophil elastase as well as levels of serum IgA antibodies to gliadin nonapeptides, tissue transglutaminase and epidermal transglutaminase: implications for both autoimmunity and autoinflammation involvement in dermatitis herpetiformis. Cent Eur J Immunol 2014; 39: 331-337.

Gornowicz-Porowska J, Bowszyc-Dmochowska M, Seraszek-Jaros A, Kaczmarek E, Dmochowski M. Loss of correlation between intensities of desmoglein 2 and desmoglein 3 expression in basal cell carcinomas. Acta Dermatovenerol Croat 2011; 19: 150-155.

Gornowicz-Porowska J, Dmochowski M, Pietkiewicz P, Bowszyc-Dmochowska M. Mucosal-dominant pemphigus vulgaris in a captopril-taking woman with angioedema. An Bras Dermatol 2015; 90: 748-751.

Gornowicz-Porowska J, Pietkiewicz P, Bowszyc-Dmochowska M, Dmochowski M. The BP180 IgG ELISA is superior to the BP230 IgG ELISA for diagnosing IgG-mediated subepidermal autoimmune blistering dermatoses. Dermatologia Kliniczna 2012b; 14: 111-116.

Gornowicz-Porowska J, Pietkiewicz P, Bowszyc-Dmochowska M, Dmochowski M. Immunoglobulin G4 is prevailing over immunoglobulin G1 in autoimmunity of pemphigus and bullous pemphigoid: analysis of tissue-bound antibodies in active diseases. Cent Eur J Immunol 2013; 38: 80-91.

Gornowicz-Porowska J, Seraszek-Jaros A, Bowszyc-Dmochowska M, Kaczmarek E, Dmochowski M. Immunoexpression of IgA receptors (CD89, CD71) in dermatitis herpetiformis. Folia Histochem Cytobiol 2017; 55: 212-220. 
Gornowicz-Porowska J, Seraszek-Jaros A, Kaczmarek E, Dmochowski M, Bowszyc-Dmochowska M. IgA autoantibodies to gliadin nonapeptides, tissue transglutaminase and epidermal transglutaminase are associated, but unrelated to neutrophil elastase expression in lesional skin in human dermatitis herpetiformis. Adv Dermatol Allergol 2012d; 29: 233-239.

Kazmierowski M and Bowszyc-Dmochowska M. Kriochirurgia w chorobach skory/Cryosurgery in skin diseases. Wydawnictwo Czelej, Lublin 2017: 1-206.

Luczkowska M. Stezenie TNF- $\alpha$ w surowiczy chorych leczonych fototerapia retinoidami $z$ powodu luszczycy/Concentration of TNF- $\alpha$ in serum of psoriasis patients treated with phototherapy and retinoids. Poznan 2006:1-116.

Mackiewicz-Wysocka M, Bowszyc-Dmochowska M, Strzelecka-Weklar D, Danczak-Pazdrowska A, Adamski Z. Basal cell carcinoma - diagnosis. Contemp Oncol 2013; 17: 337-342.

Olek-Hrab K, Osmola-Mankowska A, Silny W, Bowszyc-Dmochowska M, Danczak-Pazdrowska A, Sadowska A. Use of UVA1 in the treatment of mycosis fungoides - case report. Adv Dermatol Allergol 2011; 28: 158-164.

Osmola-Mankowska A, Silny W, Danczak-Pazdrowska A, Bowszyc-Dmochowska M, Olek-Hrab K, Sadowska-Przytocka A, Czarnecka-Operacz M. A case of a Comel-Netherton syndrome patient treated with UVA1 phototherapy. Adv Dermatol Allergol 2011; 28: 418-421.

Pietkiewicz P, Gornowicz-Porowska J, Bartkiewicz P, Bowszyc-Dmochowska M, Dmochowski M. Reviewing putative industrial triggering in pemphigus: cluster of pemphigus in the area near the wastewater treatment plant. Adv Dermatol Allergol 2017; 34: 185-191.

Pietkiewicz P, Gornowicz-Porowska J, Bowszyc-Dmochowska M, Dmochowski M. Malignancy in Relation to Autoimmune Blistering Dermatoses: Molecular and Clinical Aspects. Chapter 6 In Skin Cancer ISBN 980-953-307-766-1 edited by Pierre Vereecken, Publisher: InTech, Rijeka, Croatia 2013:159-210.

Pietkiewicz P, Gornowicz-Porowska J, Bowszyc-Dmochowska M, Dmochowski M. A retrospective study of antihypertensives in pemphigus: a still unchartered odyssey particularly between thiols, amides and phenols. Arch Med Sci 2015; 11: 1021-1027.

Pietkiewicz P, Gornowicz-Porowska J, Bowszyc-Dmochowska M, Jagielska J, Helak-Lapaj C, Kaczmarek E, Dmochowski M. Discordant expression of desmoglein 2 and 3 at the mRNA and protein levels in nodular and superficial basal cell carcinoma revealed by immunohistochemistry and fluorescent in situ hybridization. Clin Exp Dermatol 2014a; 39: 628-635.

Pietkiewicz P. Ekspresja desmoglein w rakach podstawnokomorkowych w odniesieniu do cech klinicznohistologicznych nowotworu/Desmoglein expression in basal cell carcinomas in the relation to clinico-pathological fetures of the neoplasm. Poznan 2014b: 1-137.

Polanska A, Bowszyc-Dmochowska M, Olek-Hrab K, Adamski Z, Zaba R, Danczak-Pazdrowska A. High-frequency ultrasonography a new quantitative method in evaluation of skin lymphomas-First comparative study in relation to histopathology. Skin Res Technol 2019; 82: 1735-1740.

Polanska A, Bowszyc-Dmochowska M, Zaba R, Adamski Z, Pazdrowski J, Danczak-Pazdrowska A. High-frequency ultrasonography (20 MHz) in circumscribed palmar hypokeratosis - new observations. Arch Med Sci 2016; 12: 1389-1391.

Polanska A, Danczak-Pazdrowska A, Olek-Hrab K, Osmola-Mankowska A, Bowszyc-Dmochowska M, Zaba R, Adamski Z. High-frequency ultrasonography - new non-invasive method in assessment of skin lymphomas. Skin Res Technol 2018; 24: 517521.

Schmidt E, Goebeler M, Hertl M, Sárdy M, Sitaru C, Eming R, Hofmann SC, Hunzelmann N, Kern JS, Kramer H, Orzechowski HD, Pfeiffer C, Schuster V, Sporbeck B, Sticherling M, Worm M, Zillikens D, Nast A. S2k guideline for the diagnosis of pemphigus vulgaris/foliaceus and bullous pemphigoid. J Dtsch Dermatol Ges 2015; 13: 713-727. 
Wolnik-Trzeciak G, Danczak-Pazdrowska A, Bowszyc-Dmochowska M, Dmochowski M. Glowne bialko zasadowe eozynofilow (eosinophil major basic protein-MBP), IL-5, elastaza neutrofilowa i IL-8 w skorze zmienionej pecherzowo a surowicze przeciwciala IgG przeciwko NC16a w ludzkim pemfigoidzie pecherzowym. Dermatologia Kliniczna 2005; 7: 11-15.

Wolnik-Trzeciak G, Hochol A, Bowszyc-Dmochowska M, Dmochowski M.Kliniczne, drobnowidowe i molekularne cechy zajecia mieszka wlosowego w autoimmunizacyjnych dermatozach pecherzowych. Dermatologia Kliniczna 2006; 8: 114-120.

Wolnik-Trzeciak G. Autoimmunizacja wobec naskorkowej i tkankowej transglutaminazy w odniesieniu do wybranych czynnikow skornej patogenezy opryszczkowatego zapalenia skory. Poznan 2005: 1-114. 